\title{
Denkbeelde oor God by Hosea ${ }^{1}$
}

W S Boshoff

Department Ou Testament

Universiteit van Suid-Afrika

\section{ABSTRACT}

\section{Conceptions of God in Hosea}

The book Hosea could be characterised as a polemic against particular traits of Israelite religion. According to the book's message Yahweh was deeply involved in Israel's everyday existence. His involvement is presented in terms of three critically important aspects of His being as the only God: He is God of history, God of nature and He is the High God. The basic premise that Yahweh was the God of Israel's past is common ground between Hosea and his contemporaries, but the prophet's message is that Yahweh also governs the present and future. The Israelites are moreover accused that they depend on the 'baalim' for their natural and agricultural needs. Now Yahweh is proclaimed as the God in command of every aspect of nature and fertility. Although He is a High God, Yahweh is not remote, but close by. He does make a difference and He is very relevant to Israel's everyday existence.

\section{INLEIDEND}

'n Godsdiens-historiese benadering tot Ou-Testamentiese gegewens vereis 'n onbevange lees van die Bybelse materiaal. Die teks bied 'n enkele en bevooroordeelde weergawe van die omstandighede. Só beskou, is die $\mathrm{Ou}$ Testament nie 'n handboek vir die godsdiensgeskiedenis van Israel nie, omdat geskiedskrywing vereis dat verskillende perspektiewe op 'n onderwerp of era die skrywer moet informeer. Die Ou-Testamentiese teks het in werklikheid deur 'n eeuelange suiwerings- en herinterpretasieproses gegaan om te verseker dat dit nie afwykende standpunte propageer nie. Gevolglik staan B O Long skepties oor die historiografiese moontlikheid om 'n geskiedenis van die vóór-eksiliese Israel te kan skryf, juis omdat hy meen dat die Bybelse gegewens oor die gebeure die enigste data is waarmee so 'n geskiedenis geskryf sou kon word. Hy beskryf die Bybel, as brondokument vir geskiedskrywing, as "a single amalgamated, culturally self serving and essentially private version" van die geskiedenis ${ }^{2}$.

Dit sou dus 'n fout wees om die Ou-Testamentiese gegewens onkrities te beskou as 'n betroubare weergawe van die godsdiens van ou Israel, 
asof daar oor so 'n onderwerp in die enkelvoud gepraat kan word. Daarvoor is die lewe te veelkantig. Dit sou egter nog 'n groter fout wees om voor te gee dat die Ou Testament geen waarde het as ' $n$ bron by godsdiensgeskiedskrywing nie. Daarvoor is die profetiese pleidooie en die religieuse polemiek in die historiese boeke te spesifiek die neerslag van lewensgetroue omstandighede ${ }^{3}$.

\section{OM GODSDIENSGESKIEDENIS NA TE VORS}

"Godsdiensgeskiedenis" beteken hier 'n ondersoek na die geskiedenis van gebruike, ontwikkelinge en veranderinge binne-in 'n godsdiens (intragodsdienstige dinamiek) sowel as die interaksie tussen godsdienste (intergodsdienstige dinamiek). Dit is 'n poging om reg te laat geskied aan gelyktydige verskille binne die godsdiens van ou Israel. 'n Wesenskenmerk van godsdiens is volgens $\mathbf{G}$ Lanczkowski die meervlakkigheid daarvan - 'n fenomeen wat hy kernagtig beskryf met die term religionsinterner Pluralis$m u s^{4}$. Lanczkowski beskou die verskeidenheid binne godsdienste as 'n uitbreiding op die verskeidenheid wat deur verskillende godsdienste verteenwoordig word:

"Mit hinblick auf die Vielzahl eigenständiger Religionen ist die pluralistische Situation nicht erschöpft. Sie wird vielmehr potenziert durch pluralistische Erscheinungen innerhalb dieser Religionen" 5 .

Dit behels in wese dat daar op enige stadium in die bestaan van enige godsdiens 'n verskeidenheid kenmerke, opvattings, tradisies en beklemtonings waargeneem kan word wat gelyktydig voorkom. Soms lei dit tot afskeiding en sektevorming, maar heel dikwels bestaan die verskillende vorme binne 'n godsdiens tegelyk en naasmekaar. Die situasie kan ook voorgestel word as horisontale of vertikale "gelaagdheid" wat in godsdienste voorkom 6 .

Die werklikheid van religionsinterner Pluralismus word dikwels nie doelbewus verreken in die beskrywing van godsdiensgeskiedenis nie. Dit gebeur geredelik dat ' $n$ baie stellige beskrywing, van byvoorbeeld die godsdiens van oud-Israel, gegee word met die implisiete betekenis dat 'n enkelvoudige beskrywing daarvan gegee kan word. Godsdiens, soos die lewe self, is egter meer ingewikkeld as vereenvoudigde skemas. Nie slegs die neerslag van die "amptelike" godsdiens, in die vorm van tradisies, geskrifte, besluite, ensovoorts, is van belang vir die verstaan van enige godsdiens nie, maar ook die "populêre" geloof van die gewone mense? Ook die "afwykende" opvattings in 'n godsdiens is van belang, en dikwels noodsaaklik, in die poging om 'n godsdiens se geskiedenis te verstaan. 
Dit is waardevol om in 'n godsdiens-historiese studie doelbewus rekening te hou met insigte uit die veld van die vergelykende godsdienswetenskap. $\mathrm{M}$ Eliade maak gewag van "two divergent but complementary methodological orientations" en stippel dit soos volg uit:

"One group concentrate primarily on the characteristic structures of religious phenomena, the other choose to investigate their historical context. The former seek to understand the essence of religion, the latter to discover and communicate its history" 8 .

Hierdie ondersoek na denkbeelde oor God by Hosea val in die tweede groep wat Eliade identifiseer: ten grondslag van die studie lê 'n belangstelling in die historiese konteks van Israel se godsdiens. Die wyse waarop die historiese tradisies van Israel in Hosea gebruik word, bied intra-godsdienstige inligting oor Hosea se posisie binne die breë Jahwistiese denk- en kanoniese raamwerk en dit help om die polemiek teen die tydgenootlike godsdiens, wat in die boek vervat is, op te helder'. As uitgangspunt word die beginsel geneem dat alle elemente van die godsdiens eerbiedig word vir wat dit is. In 'n eksegetiese studie doen 'n begrip soos die fenomenologiese epoche weliswaar vreemd aan, maar in soverre as wat hierdie studie godsdiensvergelykend werk, is epoche (die opskorting van vooropgesette idees rakende die studie-objek) wel ter sake ${ }^{10}$.

\section{OM OOR GOD NA TE DINK: DENKBEELDE OOR GOD BY HOSEA}

Die boek Hosea is die neerslag van polemiese omstandighede. Dit is die resultaat van die botsing van idees. Die profeet Hosea, wat in die agste eeu voor Christus geleef het, het in konflik gekom met idees oor die politiek, kultus en godsopvattinge wat in die kontemporêre Israelitiese samelewing gangbaar was. Ná sy tyd het sy standpunte, sowel as dié wat hy bestry het, voortgeleef. Sy profetiese pleidooie is weer deur volgende geslagte opgeneem en heraktualiseer, tot die mate dat hy as 'n profeet van Jahwe erken is. Die standpunte waarteen hy te velde getrek het, het in sekere kringe in Israel eweneens bly voortleef, wat aan sy boodskap 'n blywende karakter gegee het.

In moderne beoordelings van Hosea se polemiek word dikwels na sy standpunte verwys as suiwer, outentieke Jahwisme, terwyl sy teenstanders hulle aan afwykende en vals denkbeelde skuldig gemaak het. By die aandagtige lees van die boek word dit egter duidelik dat daar in die dinamiese proses van die polemiek ten minste drie vorms van interaksie plaasvind: 
* eerstens word ' $n$ beroep gedoen op die gemeenskaplike opvatting tussen Hosea en sy teenstanders dat Jahwe die God van Israel se geskiedenis is;

* tweedens word daar aangesluit by die denkbeelde van die teenstanders se godsopvattinge en gevolglik word Jahwe voorgehou as die God wat die natuur beheers;

* derdens word die grondliggende verskil, dat Jahwe in Hosea beskou word as 'n God wat betrokke, naby en relevant is, gekontrasteer met die teenstanders se ervaring dat Jahwe ver is, 'n God wat deur ander wat nader en meer betrokke is, aangevul moet word.

\subsection{Jahwe as God van die geskiedenis}

'n Bloot oppervlakkige lees van Hosea het 'n mens reeds laat besef dat die geskiedenis ' $n$ besondere plek in die boek beklee. Enersyds baseer Jahwe volgens die profeet sy aanspraak op Israel op gebeure wat in die verlede plaasgevind het. Andersyds word besondere klem geplaas op die hede en Jahwe se eis dat Israel se lewe moet ooreenstem met die konsekwensies van die verbintenis tussen hulle. Derdens plaas Jahwe se beloftes en dreigemente ook die toekoms vir Israel in die sentrum van nadenke. 'n Opvallende patroon in die uitsprake van Hosea is dat daar dikwels in die dreigemente en beloftes gebruik gemaak word van omkering en herhaling van vroeëre gebeure, soos die skepping, die uittog uit Egipte, die woestyntog en die landinbesitneming.

Ten spyte van die uitvoerige aandag wat die geskiedenis in die boek ontvang, is dit nie 'n geskiedenisboek of 'n eerstehandse historiese bron nie. Die historiese gegewens in die boek staan in diens van die boodskap wat die boek verkondig en kan nie los gesien word van die boek se teologie en wordingsgeskiedenis nie.

\subsubsection{Jahwe as God van Israel se verlede}

Die feit dat Jahwe Hom in die verlede met Israel bemoei het, vorm in Hosea die basis vir Jahwe se eis om eksklusiewe verering deur die Israeliete. Uit die studie het geblyk dat die profeet goed onderlê was in die historiese tradisies van Israel. Die uittog- en woestyntradisies en in 'n mindere mate ook die tradisies rondom die landinbesitneming is gebruik om Jahwe se aanspraak op Israel as sy volk te begrond. Die historiese waarheid of historisiteit van die tradisies word nie hier oorweeg nie, maar wel die aanwending van die historiese tradisies en die betekenis wat daaraan geheg word. 
Die voorstelling van die geskiedenis van Israel in Hosea is 'n geïdealiseerde beeld van die vroeë geskiedenis en dit word aan die hand van huweliksmetaforiek toegelig. Jahwe het volgens dié weergawe van die geskiedenis vir Israel gevind soos 'n bruidegom sy bruid ontdek: rein en ongeskonde. Die verbintenis is gesluit ten tyde van die bevryding uit Egipte. Deur die hele woestyntyd wat gevolg het was Israel op Jahwe alleen as hulle God aangewese, maar toe die woestyntyd ten einde geloop en die Israeliete hulle in die beloofde land tuisgemaak het, het hulle "ontrou" aan Jahwe geword". Dit was die begin van 'n godsdienstige agteruitgangsproses, wat in die profeet se tyd reeds so ver gevorder het dat daar volgens hom nie werklik meer van ' $n$ verbintenis tussen Jahwe en Israel sprake kon wees nie. Dit was in dié omstandighede van 'n radikaal ontaarde godsdienstige situasie dat die profeet dit nodig gevind het om in die krasste moontlike taal oor die "ontrou en owerspel" van Israel, Jahwe se metaforiese eggenote, te praat ${ }^{12}$. Die aanleiding tot die taal en uitdrukkingswyse in die metaforiek het Hosea in die kontemporêre natuurgodsdiens gevind. Dit wat op grond van die geskiedenis ' $n$ Jahwe-gerigte kultus behoort te gewees het, het volgens die profeet ontaard in 'n natuurgeoriënteerde kultus waar daar eer aan die "baäls" betoon is. Dié ontaarde kultus kon Hosea slegs toepaslik beskryf deur dit in seksuele en orgiastiese terme te doen. Daarvoor gebruik hy die negatiewe kant van die huweliksbeeldspraak: beelde van owerspel, ontrou, egskeiding en vervreemding.

\subsubsection{Jahwe as God van Israel se hede}

Jahwe se optrede in die verre verlede het die verbintenis tussen Hom en Israel tot stand gebring. Maar dit was nie bedoel om die einde van Jahwe se betrokkenheid by die volk te wees nie. Trouens, die feit dat Jahwe steeds aktief is en dat Hy steeds ' $n$ troue verbintenis van Israel se kant verwag, staan sentraal. Die probleem het egter by Israel gelê. Hulle toewyding aan Jahwe het sodanig afgeneem dat daar nie meer sprake van 'n verbintenis met Jahwe kon wees nie. Uit die perspektief van die profeet word die godsdiens wat Israel beoefen het, beskryf as 'n ontaarde godsdiens waardeur Israel hulleself van Jahwe gedistansieer het. Dit het gebeur terwyl die bedoeling van die kultus juis was om die volk naby aan Jahwe te laat leef.

In die alledaagse gang van sake het Jahwe alle lewensnoodsaaklike gawes van die natuur en landbou aan Israel geskenk, maar volgens die profeet het hulle geleef asof dit van ander gode afkomstig was. Terwyl Jahwe as "getroue eggenoot" hulle lewenstog aan Israel voorsien en hulle 
veiligheid gewaarborg het, het hulle as "ontroue eggenote" rondhoereer en deur 'n ontaarde kultus en verkeerde politieke bondgenootskappe probeer om hulle "minnaars" na te jaag om sodoende hulle lewensomstandighede te verseker.

In hulle ontrou aan Jahwe het die volk geen korrekte leiding van die priesters ontvang nie. Trouens, die priesters wat eintlik die mense was wat die volk aangaande Jahwe moes leer, het die volk in hulle sondige optrede voorgegaan. Die gevolg van Israel se ontrou was dat Jahwe se aktiwiteite in negatiewe en bedreigende aksies oorgegaan het. Enersyds is aangekondig dat die verbintenis tussen Jahwe en Israel verbreek is en andersyds is gedreig met toekomstige optrede wat aan hierdie distansiëring gestalte sou gee.

Deur die argument dat Jahwe óók God van die teenwoordige tyd is, beklemtoon Hosea die feit dat Jahwe se relevansie vir Israel nie bloot in historiese gebeure lê nie. Die boodskap is dat Jahwe steeds 'n verskil maak en dat Hy dáárom saak maak. As Jahwe bloot 'n God was wat in die verre verlede aktief was, sou dit nie sinvol wees om die eis te stel dat Israel Hom behoort te vereer nie. Die teendeel is egter Hosea se hele pleidooi: Gegrond op historiese gebeure maak Jahwe nou aanspraak op Israel se verering en toewyding, anders sou Hy ingryp en hulle in die toekoms van hulle lewensmoontlikhede ontneem.

\subsubsection{Jahwe as God van Israel se toekoms}

Die verbintenis tussen Jahwe en Israel wat volgens Hosea de facto reeds verbreek was weens Israel se ontrou, lei tot twee soorte uitsprake oor die toekoms.

Die eerste tipe uitspraak is dreigemente dat Jahwe Israel sal verwerp soos wat hulle Hom verwerp het. Die dreigemente behels straf weens hulle oortredings en ontrou op die terreine van die kultus, interne en internasionale politiek en militêre optrede. Die straf op die kultiese terrein behels dat Jahwe Hom aan die kultus sal onttrek, dat Hy die offers nie sal aanvaar nie en dat $\mathrm{Hy}$ sal toelaat dat die heiligdomme tot niet gaan en verval. Op die terrein van hulle internasionale politiek sal Hy toelaat dat dieselfde moondhede met wie Israel verdrae wou sluit, hulle vyande word, sodat Israel in die magstryd tussen die groot moondhede vergruis sou word. Op die terrein van hulle interne politiek sal Jahwe hulle koningshuis onstabiel laat word, terwyl die straf op hulle militêre oormoed die vernietiging van hulle militêre mag sou wees.

Die dreigement van Jahwe is dat Israel die land wat Hy aan hulle geskenk het, gaan verloor. Hy wat self die land in die verre verlede aan 
hulle gegee het, sal dit as vergelding vir hulle ontrou weer terugneem. Hulle sal nie slegs hulle land verloor nie, hulle sal ook na "Egipte terugkeer", wat beteken dat die toestand van slawerny wat vóór Jahwe se ingryping in hulle geskiedenis geheers het, weer sal intree. Die hele vervreemdingsproses word in metafore uitgedruk wat verband hou met die verbrokkeling van 'n huwelik: Jahwe sal Israel as vervreemde eggenote ontklee en haar verneder en niemand sal haar kan red nie; Hy sal haar nie versorg nie; Hy sal die voorsiening van lewensmiddele soos kos en kleding staak en haar van dors laat sterf. Meer nog, Hy sal dit ook vir haar onmoontlik maak om haar minnaars weer te bereik.

Die tweede tipe reaksie is die beloftes van toekomstige herstel van die verbintenis tussen Jahwe en Israel. In Hosea kom die tema van 'n nuwe begin telkens na vore. Alhoewel die profeet vir Israel dikwels tot bekering oproep, stel hy dit duidelik dat hulle ' $n$ herstelde verbintenis nie uit eie beweging kan bewerkstellig nie, aangesien hulle Jahwe nie werklik "ken" nie. Die boodskap is dat die hele geskiedenis tussen Jahwe en Israel van vooraf sal moet begin (en ook hierdie nuwe geskiedenis beeld hy uit deur middel van huweliksmetafore): Jahwe sal Israel teruglok na die woestyn en dáár sal Hy haar van vooraf die hof maak en Hom aan haar verloof. Hy sal Hom, soos in 'n huwelik, weer aan haar verbind en sy sal Hom in volle oortuiging noem "my man!".

Hosea 14 handel by uitstek oor die nuwe verhouding tussen Jahwe en Israel. Daarin word beklemtoon dat die nuwe verbintenis Jahwe se werk sal wees. Daar word in haas ongekende natuurterme oor Jahwe en Israel en oor die nuwe verhouding tussen hulle gepraat. Die boodskap is dat 'n "nuwe Israel" die toekoms ingaan saam met 'n "nuwe Jahwe", want daar word in nuwe terme oor Hom gedink en gepraat.

Die heilsbeloftes waarvolgens die verbintenis tussen Jahwe en Israel in die toekoms herstel sal word, is een van die unieke kenmerke van die profesie van Hosea. Sommige kommentatore beskou enige heilswoorde in Hosea as duidelike tekens van 'n latere (optimistiese) hersiening van die boek se boodskap, maar die tema is so deeglik in die hele struktuur van die boek verweef dat dit nie as sekondêre materiaal beskou hoef te word nie. Waar sekere gegewens wel as latere toevoegings uitgewys kan word, doen dit nie afbreuk aan die wesenlike boodskap van die boek nie. Trouens, die moderne leser kry daardeur 'n indruk van hoe die Hosea-tradisie voortgeleef het.

In die uitsprake oor die toekoms word dikwels na vroeëre gebeure verwys, maar dan nie bloot as gebeurtenisse in Israel se geskiedenis nie. In sommige gevalle word 'n historiese tradisie omgekeer en sodoende tot niet 
gemaak. In ander gevalle word die geskiedenis as 't ware herhaal om die verhouding tussen Jahwe en Israel te herstel. Dit gebeur dikwels dat een tradisie op albei maniere heraktualiseer word. Voorbeelde hiervan is:

* die skepping wat enersyds omgekeer sal word om tot die dood van "die land en alles wat daarop woon" te lei (Hos 4:3), maar wat andersyds herstel sal word as aanleiding tot die eskatologiese herstel van verhoudinge tussen Jahwe en Israel (Hos 2:20,23-24);

* die uittog uit Egipte wat omgekeer sal word in 'n "terugkeer na

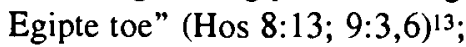

* die suggestie van 'n omgekeerde woestynervaring (Hos 2:5,11,14; 9:6b) waarvolgens Israel eintlik deur die "woestyn" (in die vorm van droogte en ongeordende woesteny) oorval sal word, terwyl die woestyntyd volgens Hosea 'n positiewe ervaring was (vgl Hos 9:10) wat herhaal sal word om die verhouding te herstel (Hos 2:16-17); die landinbesitneming wat enersyds omgekeer word deurdat Israel die gawe van die land sal verloor (Hos 9:3), maar wat andersyds herhaal word deurdat "die bewoners sal terugkeer" om die land weer te bewoon en te bewerk (Hos 14:8).

\subsection{Jahwe as God wat die natuur beheers}

In die polemiek wat Hosea teen die godsdiens van sy tydgenote voer, reken hy met Jahwe se historiese betrokkenheid by Israel as gemeenskaplike vertrekpunt met sy teenstanders. Die polemiek word egter oor twee kwessies op die spits gedryf:

* Jahwe se voortgesette betrokkenheid by Israel; asook

* die aard en reikwydte van Jahwe se aktiwiteitsveld.

In die voorafgaande twee paragrawe (3.1.2 en 3.1.3) is reeds probeer om aan te dui dat Hosea Jahwe se voortgaande betrokkenheid by Israel as ' $n$ voldonge feit beskou het. Daar word in Hosea egter tot groot uiterstes gegaan om aan te dui dat Jahwe veel meer was as net die God van Israel se geskiedenis (in die verlede, hede én toekoms).

Hosea verkondig dat Jahwe ook die natuur beheers, 'n terrein wat tradisioneel deur die natuurgode - manlik en vroulik - van die Semitiese panteon oorheers is. Soos die polemiek in die boek ontvou, word dit egter duidelik dat verskeie argumente gerig is teen elemente van die kontemporêre Jahwe-verering. Dit plaas die polemiek binne die kader van religionsinterner Pluralismus en beteken dat die stryd grootliks "na binne" gevoer is om die suiwerheid van die Jahwe-kultus in Israel, soos Hosea dit gesien het, te verseker. Terselfdertyd is daar ook 'n aanwysbare polemiek 
"na buite", teen die vreemde (oftewel Kanaänitiese) natuurgodsdiens. In die literatuur is dít die polemiek wat die meeste aandag gekry het ${ }^{14}$.

\section{Ekskurs: Kosmiese sakraliteit, "natuurgode" en "vrugbaarheidsgode"}

Natuur en vrugbaarheid hou ten nouste met mekaar verband. Dit is bykans onmoontlik om oor die natuur en die sakraliteit van die kosmos te praat sonder om die onderwerp van vrugbaarheid by die gesprek te betrek. Natuur impliseer lewe en lewe het reproduksie (die voortbestaan van die spesie) ten doel: dít is vrugbaarheid. Die vrugbaarheid van mens, dier en saailand is met 'n sakraliteit omgewe. Onmiddellike vrugbaarheid is belangrik, maar veral sekerheid oor voortgesette vrugbaarheid is wesenlik deel (en doel) van talle natuurgeoriënteerde rituele, gebruike en taboes ${ }^{15}$.

Die wyse waarop daar in Hosea enersyds 'n hewige polemiek gevoer word teen die natuurgodsdiens, terwyl terme en kategorieë uit die natuurgodsdiens andersyds gebruik word om Jahwe te beskryf, getuig van die godsdienshistoriese dilemma waarin die Jahwisme sigself bevind het. Die Jahwisme kon volgens Hosea teologies nie saam met die Baälgodsdiens bestaan nie (Hos 2:18-19). Fenomenologies gesproke kon die Jahwisme egter ook nie relevant wees indien die terrein van die Baälgodsdiens as natuurgodsdiens, nie deel uitgemaak het van die magsdomein van Jahwe nie. Die Jahwisme moes relevante antwoorde bied om vir die vereerders van Jahwe relevant te kon bly.

Die interaksie met die natuurgeoriënteerde godsdiensomgewing van die tyd en die invloed van die omgewing op die taal en beeldspraak van die Ou Testament bied insig in die situasie waarbinne Jahwisme algaande beslag gekry het ${ }^{16}$. Die terrein van vrugbaarheid is ' $n$ gebied waar wanvoorstelling en karikaturisering vry algemeen as polemiese instrumente in die Ou Testament aangewend is. Hiervan is Hosea 'n klassieke voorbeeld. Ter wille van die argument téén die "Kanaäniete" en hulle godsdiens is natuurgeoriënteerde kultiese gebruike gediskrediteer en sodoende beveg. $V$ ir perspektief is dit egter nodig om rekening te hou met die feit dat Israel in dieselfde bootjie as hulle tydgenote was. Hulle het byvoorbeeld ook behoefte gehad aan suksesvolle oeste. W Harrelson stel dit soos volg:

"The Israelites certainly gave large place in their thinking and in their worship to the motif of fertility. They were no less in need of ineans to ensure that crops would provide food for the coming year than were other peoples. Israelite religion was also a religion of fertility; it had to be, or it would have been of no consequence for the people. If Yahweh did not provide the grain and oil and fruit, the people could not live" (my beklemtoning) ${ }^{17}$.

Dit is belangrik om 'n mistasting wat redelik wydverspreid voorkom, naamlik dat natuurgodsdienste net oor vrugbaarheid gaan en dat dit kulties bloot om die seksuele gewentel het, reg te stel ${ }^{18}$. Andersen en Freedman stel die saak in perspektief deurdat hulle die "Kanaänitiese godsdiens" as 'n sinvolle en samehangende geheel ernstig opneem:

"There is no reason to doubt that Canaanites who were wholehearted worshipers of Baal enjoyed marital relationships. ...Baal worship was intended to enhance all sex life. Children conceived in wedlock were his gifts. The cult was intended to foster fertile marriages, not to turn the country into a brothel. The cult equally promoted abundant crops, through normal farming"19. 
Gemeet aan die totale kader van die natuurgodsdiens, kom verskillende kenmerkende funksies van die onderskeie natuurgode in Hosea ter sprake. Die aktiwiteite van Jahwe word egter byna nooit spesifiek teenoor 'n tradisionele godheid van die reën, weer, vrugbaarheid of iets dergeliks gestel nie, behalwe vir algemene, nie-spesifieke verwysings na Baäl(s). Dikwels word hulle metafories aangedui as "minnaars".

Hosea së verwysings na Jahwe as die God wat die ganse natuur beheers, kan onder die volgende temas opgesom word:

* Jahwe se beheer oor die natuurelemente;

* Jahwe se beheer oor die landbougawes;

* Jahwe se totale beheer oor alle aspekte van vrugbaarheid;

* Jahwe uitgebeeld in terme van natuurbeelde.

\subsubsection{Jahwe se beheer. oor die natuurelemente}

Alhoewel daar in Hosea nie baie klem gelê word op Jahwe se rol as Skepper nie (met die moontlike uitsondering van die verwysing na Hom as Israel se "Maker" - Hos 8:14), is die tema van skepping en die gepaardgaande beheer oor die natuurelemente wel deeglik teenwoordig. Hosea se boodskap is dat daar weens Jahwe se omvattende mag 'n goddelike samehang bestaan tussen Israel se toewyding aan Hom en die kosmiese gebeure wat hulle alledaagse bestaan raak. Hy kan die beheer tot voordeel van Israel aanwend (Hos 2:20,23-24) of dit kan as dreigement teen die volk gerig word (Hos 2:5, 4:3).

Per implikasie is Jahwe dus ' $n$ weergod wat reën kan gee of terughou.

\subsubsection{Jahwe se beheer oor die landbougawes}

In Hosea 2 waar die huweliksontrou-motief in redelike groot detail uitgewerk word, is die venynigste kritiek gerig op die feit dat Israel nie geweet het dat Jahwe die Gewer van die landbougawes was nie (Hos 2:10). Dié onkunde is vergelykbaar met 'n vrou wat haar eie man eintlik nie ken nie.

Die profeet beskou die terrein van die landbougawes as een van die sleutelterreine vir die polemiek teen Israel se "verbaäliseerde" kultus: die vroegste tekens van die ontaarde godsdiens bemerk hy juis op dié terrein (Hos 2:7). Gevolglik dreig hy dat Jahwe, deur die landbougawes terug te hou (Hos $2: 11 ; 9: 2$ ), sy mag daaroor sal bewys. Sodoende sal die Israel se ontaarde kultus wat volgehoue voorsiening moes verseker het, tot 'n einde kom (Hos 2:8). Die hoogtepunt van die kultus in Israel was die oesfees wat 
volgens Hosea 9:1-9 onder skoot kom. Die profeet eis dat die volk die kultiese gejuig en gejubel moes staak, omdat die hele feestelikheid volgens hom nie werklik ter ere van Jahwe plaasgevind het nie (Hos 9:1). In werklikheid het die beëindiging van die feestelikhede nie meer by die volk gelê nie, want Jahwe het besluit om dit self tot 'n eindè bring (Hos 9:5-6).

Eers ná die eskatologiese herstel van die verbintenis tussen Jahwe en Israel - dit is ná die "nuwe woestyntog" (Hos 2:16) - sal die landbouvoorsiening vir Israel weer na normaal kan terugkeer (Hos 2:17,23-25) en sal hulle weer koring kan verbou (Hos 14:8).

Die wyse waarop daar in Hosea beklemtoon word dat Jahwe Hom met die voorsiening van landbouprodukte bemoei, impliseer dat die profetiese tradisie (spesifiek in Kanaán) die belang van 'n God wat ook op die landbouterrein aktief is, besef én verreken het.

\subsubsection{Jahwe se totale beheer oor alle aspekte van vrugbaarheid}

Die vrugbaarheidsaspek van die natuurgodsdienste was egter nie tot die akkerbou beperk nie, maar was ook van toepassing op dierlike en menslike vrugbaarheid. Sekere elemente van Israel se kultus (soos kultiese versierings aan die gesig en om die hals, maar óók die feeste en offergebruike) is in wese gereken as deel van die vrugbaarheidskultus (Hos $2: 4,13,15 ; 4: 11-14,18-19)$ en dit het buiten produksie en vrugbaarheid op die landbouterrein ook menslike vrugbaarheid ten doel gehad en het veral op die persoonlike vlak van godsdiens funksioneer waar vroue hulle versier en deelgeneem het aan gebruike wat daarop gerig was om hulle eie vrugbaarheid te verseker ${ }^{20}$.

Die deurlopende זנה-terminologie in die boek, wat op die metaforiese vlak die volk se ontrou aan Jahwe uitbeeld, speel juis in op die tema van die persoonlike vrugbaarheidskultus, deurdat die detail van die beeldspraak aan dié kultiese gebruike ontleen word. Hieruit kan twee afleidings gemaak word: dat seksuele kultiese gebruike algemeen genoeg was om as basis vir die hele polemiek in die boek te dien en dat dit belangrik genoeg was dat die profeet dit in die aktiwiteitsfeer van Jahwe wou plaas, soos blyk uit die suggestiewe huweliksterminologie in die beloftes oor die eskatologiese herstel van die verhouding tussen Jahwe en Israel (Hos 2:16-17, 21-22, 25).

Die tema van Jahwe se omvattende beskikking oor alle aspekte van vrugbaarheid word saamgevat in die natuurbeelde van Hosea 14:6-9. 


\subsubsection{Jahwe uitgebeeld in terme van natuurbeelde}

Uit die bespreking van Jahwe as God wat die natuur beheers, het dit tot dusver duidelik geword dat Hy nie as een of ander natuurelement of as 'n natuurgod voorgestel word nie, maar juis as God wat oor elkeen van die aspekte van die natuur heers. Dit mak die enkele gevalle waar sy werksaamhede spesifiek met natuurbeelde uitgebeeld word soveel opvallender.

'n Goeie voorbeeld is Hosea 2:25 wat handel oor die eskatologiese rehabilitasie van die simboliese name van Hosea en Gomer se kinders. Die frase וזרעתיה לי בארץ ("Ek sal haar vir my in die land saai") is 'n sinspeling op die naam Jisreël en dui sekerlik op die akkerbou van die Jisreëlvlakte en Jahwe se onderneming om weer graan in oorvloed te voorsien, maar ווזעתיה ("ek sal haar saai") het ook bepaalde seksuele ondertone wat saamhang met die huweliksbeeldspraak van Hosea 2:21-22. Daarmee word Jahwe uitgebeeld as die lewegewende Eggenoot wat by wyse van geslagtelike verkeer lewe gee.

'n Verdere voorbeeld is die uitsprake van Hosea 14 wat in terme van die aanwending van natuurbeelding met Hooglied vergelyk kan word, maar die unieke in Hosea is dat dit direk met Jahwe en sy aktiwiteite verbind word. Oor Jahwe self word gesê Hy sal soos die dou wees (Hos 14:6) en dat Hy soos 'n groen sipres is (tradisioneel is dit 'n tipiese uitbeelding van die groot godin) en dat Israel hulle vrug van Hom sal vind (Hos 14:9). Jahwe se betrokkenheid by Israel word ook uitgedruk in terme van natuurbeelde en hulle beloofde voorspoed word beskryf as natuurlike groei en weligheid (Hos 14:6-8).

Hierdie unieke uitbeelding van Jahwe bring die polemiek teen die natuurgodsdiens tot 'n logiese konklusie: geen ander gode het enige rol te speel in die gang van die natuur nie. Daarom kan daar van Jahwe gesê word dat Hy soos die dou is of soos 'n groen sipres of dat Hy vrug gee. Dit gee in wese dieselfde boodskap weer as Hosea 2:11 waar gesê is dat Jahwe self die voorsiening van landbouprodukte sal beëindig. Dit plaas Hom in effektiewe beheer van die terrein wat normaalweg onder die beheer van natuur- en vrugbaarheidsgode en -godinne geval het.

\subsection{Jahwe "tussen ver en naby": die situasie van 'n "Hoë God"}

Op grond van die voorafgaande moet nou gevra word na die rede onderliggend aan die polemiek teen die godsdiensbeoefening in Israel. Daar is reeds op gewys dat die polemiek in die eerste plek intra-godsdienstig was: 
dit was 'n Jahwistiese profeet wat teen Jahwistiese tydgenote polemiseer het. Die rede vir die hewige verskille tussen Hosea en sy tydgenote lê myns insiens in hulle onderskeie opvattings oor God.

\subsubsection{Fenomenologiese opmerkings oor hoë gode}

'n Proses wat redelik deeglik in godsdiensfenomenologiese studies gedokumenteer is, beskryf dat sekere gode (die "Hoë Gode") weens hulle aard en werksaamhede uit die onmiddellike sfeer van relevansie vir hulle vereerders uitbeweeg, terwyl ander gode (soos vrugbaarheids- en weergode) hulle plek neem, omdat hulle werksaamhede hulle nader aan die mense bring. Dit blyk dat Jahwe vir baie van Hosea se tydgenote sy relevansie verloor het deurdat hulle die terrein van die natuur en vrugbaarheid nie as deel van die magsfeer van Jahwe beskou het nie. Hulle het die gode wat tradisioneel in die wes-Semitiese wêreld vir daardie take verantwoordelik was, daarvoor vertrou en in die proses is Jahwe uit die sentrum van hulle godsdiensbeoefening geskuif. Vir Hosea was dit onaanvaarbaar. In lyn met 'n tradisie waarvolgens Jahwe eksklusief vereer is (die sogenaamde "Jahwe-alleen beweging"), het Hosea en die tradente van die Hosea-tradisie verklaar dat Jahwe die ganse werklikheid beheers en dat daar geen plek vir ander gode bestaan nie - alle ander gode is afgode 21 .

\section{Ekskurs: Die "Hoë God" (High God/Supreme Being): aard en morfologie}

Die onderwerp van die sogenaamde "hoë gode" is sedert die vroeë navorsing oor godsdiens fenomenologies bestudeer ${ }^{22}$. In die literatuur word 'n onderskeid getref tussen "hoë gode" (high gods) en die verskillende "hemelse gode" (sky gods) 23.

Kenmerkend van 'n hoë god is dat dit meestal 'n uitstaande, soms corweldigende figuur is en dat daar nie 'n kultus aan hom/haar gewy word nie. Die oorheersende kenmerk is die afstand (otiositas) van gewone mense af, sowel in terme van ruimte as in tyd. Voorts is die hoë god' $n$ goddelike gestalte op die agtergrond; die mens bly bewus van sy bestaan en sal hom selfs by geleenthede aanroep, maar sal nie verbaas wees as daar geen antwoord is nie ${ }^{24}$. E O James ${ }^{25}$ dui aan dat juis hierdie afstand en verhewenheid die hoë god ontoeganklik en onbereikbaar vir gewone gelowiges maak. M Eliade ${ }^{26}$ sluit hierby aan wanneer hy praat van die "veraf god" (remote god). Dit blyk dat die neiging om vir meer konkrete en dinamiese kragte plek te maak 'n wesenlike element van die struktuur van die oppergod is ${ }^{27}$. Die hoë god hoef nie noodwendig in hemelse terme beskryf te word nie. Sommige hoë gode is nie "hemelse vaders" nie, maar "aardse moeders". Die onderskeid hang volgens Pettazoni saam met die soort beskawing waarin die betrokke gode hulle rolle speel: agter die "hemelse vader" staan 'n lang tradisie van patriargale, pastorale beskawing; agter die "aardse moeder" staan weer 'n tradisie van 'n matriargale, landboukultuur. Volgens Pettazzoni ${ }^{28}$ spruit die mens se opvatting oor die oppergod nie soseer uit intellektuele behoeftes as uit eksistensiële onnus nie. 
Wat die presiese aard van die hoë god egter ookal is, blyk dit volgens James $^{29}$ dat hierdie "hoë gode" oral met sekondêre figure soos verheerlikte voorouers, helde, geeste of gode wat vir sekere departemente van die lewe verantwoordelik is, verbind word. Die belang van die sekondêre figure lê juis daarin dat hulle betrokke is by alledaagse sake, terwyl die oppergod eintlik 'n deus otiosus is ${ }^{30}$. Terwyl die hoë gode hulle van die alledaagse bestaan onttrek, word hulle geleidelik deur ander religieuse vorms, soos natuurgode, voorouers, vrugbaarheidskragte en son- of maangode vervang. Sullivan dui aan dat dié neiging om plek te maak vir meer konkrete en dinamiese kragte wesenlik is aan die struktuur van die oppergod ${ }^{31}$.

Dit is fenomenologies gesproke vir 'n god van die grootste belang om relevant te bly vir die mense wat hom/haar vereer. E O James stel dit so:

"To be effective, gods, whatever their rank and status, must be ritually accessible and efficacious, immanent as well as transcendent" 32 .

Verwysings daarna dat 'n god relevant moet bly, kom wydverspreid in die literatuur voor, onder meer ook in gevalle wat nie noodwendig met hoë gode in verband staan nie 33 .

Die wyse waarop 'n hoë god aan die vergetelheid ontruk kan word, is deurdat die god in 'n direkte verband tot kontemporêre gebeure en aktiwiteite gebring word ${ }^{34}$. Normaalweg word gode deur rituele gebruike teenwoordig gestel of by alledaagse gebeure betrek. E O James merk op dat die afwesigheid van 'n kultus en spesifiek van seisoensrituele vir die hoë gode baie opvallend is ${ }^{35}$. Om die relevansie van 'n oppergod te verseker, moet die god dus aan 'n kultus verbind word of op 'n ander manier as suiwer transendente wese vereer word. James meen dat daar oral 'n klein minderheid mense is wat deur die suiwer transendente aspekte van godsdiens aangespreek word, maar vir die meeste mense is die transendente aspekte van godsdiens byna uitsluitlik ter sprake by spesiale geleenthede en tye, soos geboorte, huwelik, dood, sonstilstand, saai- en oestyd ${ }^{36}$.

\subsubsection{Jahwe as Hoë én Nabye God: eksegetiese resultate}

\subsubsection{Inleidend}

Jahwe, die God van die Ou Testament, is volgens Van der Leeuw nie 'n tipiese hoë god nie, omdat Hy op wesenlike punte van tipiese oppergode verskil ${ }^{37}$. Hy beskryf Jahwe as onderskeibaar, omdat Hy 'n "animistiese" 
God is wat gekenmerk word deur sy aktiwiteit, beweeglikheid en teenwoordigheid. Jahwe is by die mens se geskiedenis betrokke én Hy is God van die reg. Alhoewel Jahwe in die hemel woon, bly Hy betrokke by gebeure op aarde ${ }^{38}$. H Niehr het meer onlangs die tema van Jahwe as Hoë God teen die agtergrond van die Siries-Kanaänitiese godsdiens ondersoek. Hy het uitgewys hoe Jahwe elke aspek van die bestaanswyse van 'n Hoë God stelselmatig beset het ${ }^{39}$.

Pettazzoni beskryf 'n strukturele dualisme in die wese van die oppergod en wys op die twee aspekte van otiositas (afstand) en intense aktiwiteit. Hy voer aan dat die kombinasie van hierdie elemente in Jahwe nie dui op die vereniging van twee strukture nie, maar op twee aspekte van 'n unieke tweesydige struktuur ${ }^{40}$. Ek meen dat die "unieke tweesydige struktuur" se oorsprong in die geskiedenis lê en dat spore van die ontwikkeling daarvan in die eksegetiese ondersoek van die boek Hosea uitgewys is.

Die voorstelling van Jahwe as Hoë God én as teenwoordige, aktiewe God is myns insiens korrek, maar dit is 'n resultaat van doelgerigte en voortdurende pogings om Jahwe as relevante God te beskou en te verkondig.

Die tydgenote teen wie Hosea polemiseer het, het Jahwe, soos húlle hom verstaan het, nie (meer) as relevant vir hulle omstandighede beskou nie. Jahwe se rol in Israel se geskiedenis is sowel deur Hosea as sy teenstanders erken. Juis daarop bou Hosea 'n deel van sy argumentasie. In die praktyk van die alledaagse, gevestigde landboubestaan het die natuurgodsdiens, gebaseer op lewenskrag en vrugbaarheid, egter aan al die behoeftes voldoen en is Jahwe as God op die agtergrond geskuif ${ }^{41}$.

\subsubsection{Tekstuele gegewens uit Hosea}

Jahwe se betrokkenheid by Israel word op tweërlei wyse in Hosea hanteer: enersyds positief en andersyds negatief.

Die positiewe stellings beeld Jahwe uit as die God wat betrokke is by elke aspek van Israel se bestaan. Hy beloof vir hulle landbougawes (Hos 2:20,23-24) en $\mathrm{Hy}$ dreig dat $\mathrm{Hy}$ hulle dit sal ontneem (Hos 2:11,14 en 4:3); Hy het hulle geskiedenis beheer (Hos 2:17) en $\mathrm{Hy}$ bepaal hulle toekoms (Hos 2:16-17); Hy verleen aan die kultus waarde of ontneem dit van enige sin (Hos 2:13, 4:6 en 14:3); kortom, deur sy betrokkenheid by hulle verleen Jahwe aan Israel bestaansmoontlikhede (Hos 14:5-9).

Die negatiewe stellings beeld Jahwe uit as die Een wat by Israel betrokke was en Hom van hulle onttrek het (Hos $2: 4,10 ; 4: 7,17 ; 5: 6 ; 8: 13$ 
en $9: 2-4$ ) of as die God wat deur Israel vergeet is (Hos $1: 2 \mathrm{~d} ; 2: 7,14-15$; $4: 1-2,6,10-12,14 ; 5: 4,7 ; 8: 3,14$ en $9: 1)$.

In die laaste plek word Jahwe met die baäls en ander (vermeende) gode gekontrasteer. Indien Jahwe besluit om Israel te veroordeel en hulle te verwerp, kan die ander gode niks doen om Israel se lot te verlig of die oordeel af te wend nie (Hos 2:5,8-9,12-15,18-19, 4:16-19 en 9:1-3). Hosea $2: 9$ is 'n goeie voorbeeld van hoe 'n taaltegniek aangewend word om die verlies aan status deur die ander gode uit te beeld. Die "minnaars" word as 't ware uit die teks uitgeskryf wat beteken dat hulle hulle relevansie verloor. lets soortgelyks word uitgebeeld in Hosea 2:8 en 12 waar op 'n heel ander manier die ander gode se onmag blootgelê word - deur op hul onvermoë te wys om werklik te kan help.

\section{SLOT}

Die gerigtheid van die Hosea-boodskap is op gewone mense en hulle alledaagse godsdiens. Hulle leefwêreld het vereis dat hulle God by dinge soos die landbou, vrugbaarheid, reën en voorspoed betrokke moes wees. Dat Jahwe só 'n God is, maar ook veel meer, is Hosea se boodskap aangaande Jahwe.

Israel word gekonfronteer met Jahwe as unieke en enigste God. Nie alleen is die "baäls" magteloos en oneffektief nie, hulle bestaan eintlik glad nie. Alle goddelike eienskappe en aktiwiteite wat aan hulle toegeskryf is, is eintlik op Jahwe van toepassing. Hy is die God van Israel se geskiedenis en ook God van die natuur. Hy is 'n Hoë God, veraf en majestueus, maar tegelyk ook naby, liefdevol en betrokke.

\section{NOTAS:}

1 Die artikel handel oor die godsdiens-historiese resultate in W S Boshoff, Die boek Hosea en die Jahwe-Baäl-stryd, Pretoria 1994, 'n DD-proefskrif wat onder leiding van prof $\mathrm{W}$ Vosloo, Departement Ou Testament, Universiteit van Pretoria, voltooi is. Finansiële ondersteuning deur die SWO vir die navorsing word hiermee erken. Die gedagtes uitgespreek en die gevolgtrekkings waartoe gekom is, is egter myne en moet nie aan die SWO toegeskryf word nie.

2 B O Long, "On finding the hidden premises", JSOT 39(1987), 10-14.

3 W S Boshoff, "Geskiedskrywing, godsdiensgeskiedenis en die Ou Testament" Theologia Evangelica 23/3(1990), 12-21.

4 G Lanczkowski, Begegnung und Wandel der Religionen, Düsseldorf 1971, 5055 . 
5 Lanczkowski, $a w, 50$. Hy beskryf afskeidings uit die tradisionele godsdiensgemeenskappe as die opvallendste vorm van interne pluralisme (50-52), maar wys ook op godsdiensgelaagdheid, byvoorbeeld in die Griekse godsdiens van die Homeriese eposse, waar onderskei kan word tussen "hoër" godsdiens van die adel en die laere godsdienssfere van die landelike vroomheid (52). Die gelaagdheid kom egter in alle godsdienste voor en soms is die afwyking van die amptelike godsdiens merkwaardig groot. Ander vorms van interne pluraliteit is beroepspesifieke godsdiens (54) en geslagsdifferensiasie binne godsdienste (55).

6 M Rose, Der Ausschliesslichkeitsanspruch Jahwes: Deuteronomistische Schultheologie und die Volksfrommigkeit in der späten Königszeit, Stuttgart 1975, 269-275; H Vorländer, Mein Gott: Die Vorstellungen vom persönlichen Gott im Alten Orient und im Alten Testament, Kevelaer 1975, 3-4; R Albertz, Personliche Frömmigkeit und offizielle Religion: Religionsinterner Pluralismus in Israel und Babylon, Stuttgart 1978, 18; R Albertz, Religionsgeschichte Israels in altrestamentlicher Zeit. Teil I: Von den Anfangen bis zum Ende der Königszeit, Göttingen 1992, 38-43.

$7 \quad$ Albertz, $a w, 1978,17$.

8 M Eliade, The sacred and the profane: The nature of religion, San Diego 1959, 232.

9 W Zimmerli, Prophetic proclamation and reinterpretation, in: D A Knight (ed), Tradition and theology in the Old Testament, London 1977, 70; W E Rast, Tradition history and the Old Testament, Philadelphia 1972, 21.

10 J S Kruger, “Reductionism' in studying religious phenomena”, Theologia Evangelica 15/2 (1982), 28; J S Kruger, Studying religion: A methodological introduction to science of religion, Pretoria 1982, 18; F E Deist, A concise dictionary of theological terms, Pretoria 1984, 55.

11 M Weippert, "Synkretismus und Monotheismus: Religionsinterne Konfliktbewáltigung im Alten Israel”, in: J Assmann \& D Harth (Hrsg), Kultur und Konflikt, Frankfurt 1990, 149 bied 'n insiggewende oorsig oor hoe die onderskeie "ideale eras" in Israel se vroeë geskiedenis by verskillende OuTestamentiese outeurs op verskillende tye in die geskiedenis tot 'n einde gekom het: tydens die woestyntog, net na die uittog (Eks 32, Deut 9:8-21, Hos 11:1-2; 13:5-6); by die ontmoeting met die mense, gode en heiligdomme van die kultuurland (Num 25, Hos 9:10); ná die dood van die "uittoggenerasie" wat nog almal getuies van Jahwe se groot dade in die geskiedenis was (Rigt 2:7-10); tydens en ná die vestiging in die land Kanaän (Rigt 3:6; 1 Kon 14:23-24; 2 Kon 17:7-12; Hos 13:1). Volgens Esegiël, egter, was Israel reeds in Egipte en al die tyd sedertdien ontrou aan Jahwe (Eseg 20; 23:3).

12 P Kruger, "Yahweh and the gods in Hosea", JSem 24(1992), 84-90. 
13 Die "terugkeer na Egipte" het hier simboliese betekenis. Dit dui op die terugkeer na 'n toestand van Godverlatenheid soos voordat Jahwe Hom in Egipte met Israel bemoei het eerder as na 'n plek, soos blyk uit die parallellisme tussen Egipte en Assur (Hos 9:3).

14 G Östborn, Yahweh and Baal. Studies in the book of Hosea and related documents, Lund 1956; D Kinet, Bu'al und Jahwe. Ein Beitrag zur Theologie des Hoseabuches, Frankfurt am Main 1977; H Balz-Cochois, Gomer: Der Hohenkult Israels im Selbstverständnis der Volksfrommigkeit. Untersuchungen zu Hosea 4,1-5,7. Frankfurt am Main 1982; H Balz-Cochois, "Gomer oder die Macht der Astarte: Versuch einer feministischen Interpretation von Hos 1-4", Evangelische Theologie 42(1982), 37-65; N A Moseley, A critical evaluation of the methods and motifs in the polemic against Baalism in Hosea. DTh Dissertation, New Orleans Baptist Theological Seminary, 1987), Ann Arbor 1988.

15 M Eliade, Patterns in comparative religion, London 1958, 331-361.

16 A M Greeley, Unsecular man: The persistence of religion, New York 1972, 179 .

17 W Harrelson, From fertility cult to worship, Garden City NY 1969, 12-13.

18 Die natuur maak deel uit van die groot geheel van die kosmiese sakraliteit en dit sluit veel meer in as blote vrugbaarheid en seksuele kultiese gebruike. Eliade, $a$ $w, 1959,125-126$, illustreer die omvangryke veld van die natuur as sodanig, deur die kontras tussen die verering van ' $n$ veraf god en die verering van die natuur as deel van die kosmiese sakraliteit te beskryf:

"The divine remoteness actually expresses man's increasing interest in his own religious, cultural, and economic discoveries. Through his concern with hierophanies of life, through discovering the sacral fertility of the earth, and through finding himself exposed to religious experiences that are more concrete (more carnal, even orgiastic), primitive man draws away from the celestial and transcendant god. The discovery of agriculture basically transforms not only primitive man's economy but also and especially his economy of the sacred. Other religious forces come into play - sexuality, fertility, the mythology of woman and of the earth and so on. Religious experience becomes more concrete, that is, more intimately connected with life. The great mothergoddesses and the strong gods or the spirits of fertility are markedly more dynamic and more accessible to men than was the Creator God" (beklemtoning deur Eliade).

19 F I Andersen \& D N Freedman, Hosea: A new translation with introduction and commentary, New York 1980, 229.

20 O Keel \& C Uehlinger, Gottinnen, Gotter und Gottessymbole: Neue Erkenntnisse zur Religionsgeschichte Kanaans und Israels aufgrund bislang 
unerschlossener ikonographischer Quellen, Freiburg im Breisgau 21993, 146147.

21 M Smith, Palestinian parties and politics that shaped the Old Testament, London 11971 | 1987, 11-42 het die klassieke beredenering van die Jahwe-alleen beweging gedoen; vergelyk ook B Lang, "Vor einer Wende im Verständnis des israelitischen Gottesglaubens?" ThQ 160(1980), 53-60; B Lang, "Die Jahweallein-Bewegung, in: B Lang (Hrsg), Der einzige Gott. Die Geburt des biblischen Monotheismus, München 1981, 47-83; B Lang, "Neues über die Geschichte des Monotheismus", ThQ 163(1983), 54-58, B Lang, "No God but Jahwe! The origin and character of biblical monotheism" in: C Geffre \& J P Jossua (eds), Monotheism, Edinburgh 1985, 41-49; B Lang, "Zur Entstehung des biblischen Monotheismus", ThZ 166(1986), 135-142; W S Boshoff, “Die monoteïsme: Vroeë rigtinggewer of laat aankomeling in die godsdiensgeskiedenis van Israel?" , ThEv 21(1988), 2-14.

22 L E Sullivan, s v 'Supreme beings', in: $M$ Eliade (ed), Encyclopedia of Religion, New York 1987, 174-180.

23 Vergelyk R Pettazzoni, "The Supreme Being: Phenomenological structure and historical development", in: M Eliade \& J M Kitagawa (eds), The history of religions: Essays in methodology, Chicago 1959, 60. Daar is egter ook coreenkomste tussen die twee soorte gode. "Hemelse gode" vertoon dikwels kenmerke van die "Hoë God" (vgl Sullivan, $a w, 166)$, terwyl die "Hoë God" dikwels aan die uitspansel (waar die "hemelse gode" woon) verbind word (vgl G Van der Leeuw, "Die Struktur der Vorstellung des sogenannten höchsten Wesens", Archiv für Religionswissenschaft, 29(1931), 91; Eliade, a w, 1958, 39). Die "Hoë God" het meestal 'n kosmogoniese element wat dui op oorsprong in sy wese, hy skep iets, bring iets tot stand ( $\mathrm{vgl}$ Eliade, $a w, 1959,122$; Sullivan, $a w, 167)$; die hemelse gode het dit nie noodwendig nie.

$24 \quad$ Van der Leeuw, $a w, 93-95$.

25 E O James, The worship of the Sky-God: A comparative study in Semitic and Indo-European religion, London 1963, 8.

26 Eliade, $a w, 1959,123-125$. Die "Hoë God" woon in die hemel of hy het hom mettertyd daarheen teruggetrek; hy was lank tevore jonk en lewenskragtig, 'n kenmerk wat A van Selms, "A forgotten god Lah" in: Studia Biblica et Semitica, Wageningen 1966, 326 ten opsigte van die Ugaritiese El beskryf. Vergelyk ook H Gese, M Höfner \& K Rudolph, Die Religionen Altsyriens, Altarabiens und der Mandaer, Stuttgart 1970, 125.

27 Sullivan, $a w, 180$

28 Pettazzoni, $a w, 64-65$. 
James, $a w, 8$.

30 Vergelyk Eliade, $a w, 1959,122$. Sullivan, $a w, 180$ beskryf Eliade se besondere bydrae tot die fenomenologiese studie van die oppergod as sy opheldering van die proses van onttrekking of verdwyning van die gode uit die onmiddellike invloedsfeer van gewone mense. Die onttrekking en gevolglike onbetrokkenheid van die hoë gode tree dikwels in nadat hulle skeppingswerk voltooi is (vgl Eliade, $a w, 1958,109$; Eliade, $a w, 1959,122 ;$ M Eliade, The quest: History and meaning in religion, Chicago 1969, 81-82; Pettazzoni $a w$, 63; James, $a w, 33$; C Olson "Theology of nostalgia: reflections on the theological aspects of Eliade's work", Numen 36(1989), 104.

31 Sullivan, a w, 180. Die proses van onttrekking deur die oppergod, wat in hierdie paragraaf ter sprake kom, is op verskeie plekke en in verskillende kulture gedokumenteer. Ten opsigte van skriflose kulture is die proses deur middel van die optekening van mitologiese vertellings en oorlewerings welbekend. Baie gegewens in dié verband is opgeteken, onder andere in die monumentale en klassieke werk van W Schmidt (1926-1955) wat weerspieël word in die voetnotas en bibliografiese notas van Eliade, $a w, 1958$ en Van der Leeuw, $a w, 84-87$. Studies van tekste uit verskeie historiese godsdienste, lewer soortgelyke resultate (vgl Van der Leeuw, a w, 97-98; A $\mathrm{H}$ van $\mathrm{Zyl}$, “Die spanning tussen ver en naby", NGTT 1(1960), 15-26).

32 James, $a w, 9$.

33 Uiteenlopende gevalle is beskryf wat dien as voorbeelde van die wyse waarop gode se vermoë om relevant te bly hul "oorlewing" aldan nie, bepaal het. Drie voorbeelde kan dit illustreer:

* Die "Aten-monoteïsme" van die Egiptiese farao Akhenaten uit die Amarnatyd, het misluk weens die gebrek aan populêre aanvaarding van die godsdiens (vgl H Frankfort, Ancient Egyptian religion. An interpretation, New York [1948] 1961, 25; James, a w, 15; W S Prinsloo, "Was die Atenreligie 'n monoteïsme?" NGTT 15(1974), 32-35).

* 'n Verdere voorbeeld van die noodsaak vir relevansie vir 'n god is dié van die onbekende (hipotetiese?) Semitiese god Lah wat 'n god sou wees van die lewensap of lewenskrag van bome wat by fonteine groei. Die wyse waarop A van Selms, $a w, 326$, die onderwerp behandel, werp lig op die feit dat 'n god wie se aktiwiteite vir niemand van belang is nie, in die vergetelheid kan raak. Veral die onderliggende teorie is hier van belang.

* 'n Derde voorbeeld vind ons by C S Song, Third-eye theology: Theology in formation in Asian settings, London 1980, 110-111, waarin hy die verhouding tussen die Christendom en Boeddhisme bestudeer. Hy skryf die manier waarop dié twee godsdienste hul aanhangers eksistensieel aanspreek toe aan die feit dat sowel Jesus as Boeddha godsdiens teruggebring het na die vlak van die gewone mense (vgl ook Van Zyl, $a w, 26$ ).

34 James, $a w, 9$. 
35 Idem, $a w, 8$. Vergelyk ook Eliade, $a w, 1959,125$.

36 James, $a w, 8$. Daar kom wel soms afwykings van die tipiese patroon van die oppergod voor, soos Eliade, $a w, 1958,110$; Eliade, $a w, 1959,122$ en Pettazzoni, a $w, 1959,61-65$ aandui.

$37 \quad$ Van der Leeuw, $a w, 98$.

38 Van der Leeuw, $a w, 98-99$. Eliade, $a w, 1959,122$ maak spesifiek gewag van die unieke verskynsel van monoteïsme as uitsondering op die reël aangaande oppergode ("supreme beings"):

The celestially structured supreme being preserves his preponderant place only among pastoral peoples, and he attains a unique situation in religions that tend to monotheism (Ahura-Mazda) or that are fully monotheistic (Yahweh, Allah).

39 H Niehr, Der hochste Gott: Alttestamentlicher JHWH-Glaube im Kontext syrisch-kanaanäischer Religion des l. Jahrtausends v. Chr, Berlin 1990, 71-163.

40 Pettazzoni, $a w, 63$.

41 Vergelyk die geskiedenis van $\mathrm{El}$ as oppergod in Ugarit en sy stryd om mag teen die weer en vrugbaarheidsgod Baäl-Haddu soos beskryf in $\mathrm{H}$ Gese, M Höfner \& $\mathrm{K}$ Rudolph, $a w, 125$ en M Eliade, A history of religious ideas, Volume 1: From the Stone Age to the Eleusinian mysteries, Chicago 1978, 151. 